\title{
The Effect of Organizational Culture, Pedagogic Competence and Work Motivation on Teacher Performance at SMP Negeri Padang Bolak in North Padang Lawas District
}

\author{
Khoirul Umri Siregar, Eka Daryanto, Ibnu Hajar \\ Learning Development Research History Education, magister of Administration Education, \\ State University of Medan, Medan, Indonesia \\ Corresponding author: khoirulumri42@yahoo.co.id
}

\begin{abstract}
This study aims to determine: (1) the effect of organizational culture on teacher work motivation; (2) the effect of pedagogic competence on teacher work motivation; (3) the effect of organizational culture on teacher performance; (4) the effect of pedagogic competence on teacher performance; and (5) the effect of work motivation on teacher performance. The subject of this research is the teacher of Public Junior High School Subdistrict Padang Bolak with the total sample of 120 people. Sampling is done by proportional simple random sampling. The research method is a path analysis that aims to test the theory and obtain information about research. Based on the results of the study concluded: (1) organizational culture have a direct positive effect on teacher work motivation, with $\rho_{31}=0,294$ and $t_{0 b s e r v e}=3,789$ with significant level 0,000 ; (2) pedagogic competence has a direct positive effect on teacher work motivation, with $\rho_{32}=\mathbf{0 , 4 3 0}$ and $t_{\text {observe }}=5,538$ with significant level 0,000 ; (3) organizational culture have a direct positive effect on teacher performance, with $\rho_{41}=0,330$ and $t_{0 b s e r v e}=$ 3,930 with significant level 0,000 ; (4) pedagogic competence has a direct positive effect on teacher performance, with $\rho 42=0,197$ and $t_{\text {observe }}=2,210$ with significant level 0,000 ; and (5) work motivation has a positive direct effect on teacher performance, with $\rho_{43}=0,198$ and $t_{\text {observe }}=2,094$ with significant level 0,000 . The results of the study provide an illustration that organizational culture, work motivation, and work motivation affect the performance of teachers Public Junior High School Subdistrict Padang Bolak.
\end{abstract}

Keywords: Organizational culture, Pedagogic competence, Work motivation, Teacher performance

\section{INTRODUCTION}

The school has a characteristic that is adopted as a guideline in carrying out an organization. In a school, there are certainly organizations in it and there are human resources such as principals, teachers and students.

School organization culture is a tool to increase teacher commitment and behavior. The school's organizational culture comes from the founder of the school itself, not the influence of other school cultures or other external factors

One that affects teacher performance is work motivation. Work motivation is an internal factor of the teacher. The existence of work motivation in the teacher also affects the high and low performance of the teacher.

A teacher must have pedagogic competence. The pedagogic competence of teachers is influenced by. Pedagogic competence is one of the competencies that must be possessed by a teacher. In this case, the teacher is able to master the characteristics of students, master learning theory and the principles of learning that educate. In this case, the teacher is also required to develop the curriculum. Curriculum development conducted by teachers must be able to produce innovative, meaningful learning. Mastery of pedagogic competence is closely related to the ability of teachers to learn. this competence is an important part of the teacher's main task.

Judging from the school organizational culture, an average of $60 \%$ of teachers at North Padang Lawas Middle School can work optimally if supervised by the principal. Judging from its pedagogical competence, teachers lack mastery of pedagogic competence. So that its ability to carry out learning activities, master learning theory and principles of learning, is unable to develop curriculum, and does not develop learning evaluation tools. Judging from the work motivation of teachers, as many as $70 \%$ of the average teachers at SMP Negeri Padang Bolak in North Padang Lawas District have high work motivation led by participatory principals.

This indicates that the influence of teacher competency on teacher motivation is dominant, and to increase teacher motivation other policies are not needed in addition to teacher competence. Based on the background of the problem, this study was conducted to determine the effect of organizational culture, teacher's pedagogical competence, and teacher's work motivation 
on the performance of teachers of SMP Negeri Padang Bolak in North Padang Lawas District.

In accordance with the problems that have been formulated in the previous section that will find a solution, the purpose of this study is to find out:

1. Direct influence between school organizational culture on the work motivation of teachers at SMP Negeri Padang Bolak in North Padang Lawas District.

2. Direct influence between pedagogic competency on the work motivation of teachers at SMP Negeri Padang Bolak in North Padang Lawas District.

3. Direct influence between school organizational culture on the performance of teachers at SMP Negeri Padang Bolak in North Padang Lawas District.

4. Direct influence between teacher's pedagogic competency on the teacher's performance at SMP Negeri Padang Bolak in North Padang Lawas District.

5. Direct influence between work motivation on the teacher performance at SMP Negeri Padang Bolak in North Padang Lawas District.

The word performance in Indonesian is the translation of the word in English Performance which means work, deed, appearance and performance. performance can be interpreted as work performance, work performance, work achievement, or performance. [1] Mulyasa Performance is also called performance, performance is the result achieved by a person in carrying out his work according to the size that applies to the work in question. Suprihatiningrum[2]

[3]Robbins and Judge (in Harijanto) give limitations on organizational culture as follows: "organizational culture refers to a system of shared meaning held by members of the organization from other organizations". This means that organizational culture refers to a system of shared meaning formed by its members as well as differentiating organizations.

Meanwhile, according to [4]Luthans (in Harijanto) organizational culture is "a pattern of basic assumptions invented, discovered, or developed by a given group as it learns to cope with problems of external adaption and internal integration that has worked well enough to be considered valuable and therefore, to be taught to new members as the correct way to perceive, think, and feed in relation to those problems ". From this definition it seems that the organizational culture actually grows because it is created and developed by individuals who work in an organization, and is accepted as values that must be maintained and passed on to each new member. These values are used as guidelines for each member as long as they is within the organization's environment and can be considered as a characteristic that distinguishes an organization from other organizations.

[5]McDonald (in Hamalik) states "motivation is an energy change within the person is characterized by affective arousal and anticipatory goal reaction". Motivation is a change in energy in a person that is characterized by the emergence of feelings and reactions to achieve goals" .

This research will look for the influence of organizational culture by principals, teacher's pedagogic competence, and teacher's work motivation on teacher performance at SMP Negeri Padang Bolak in North Padang Lawas District. At the bottom of the framework, the research framework is as follows:

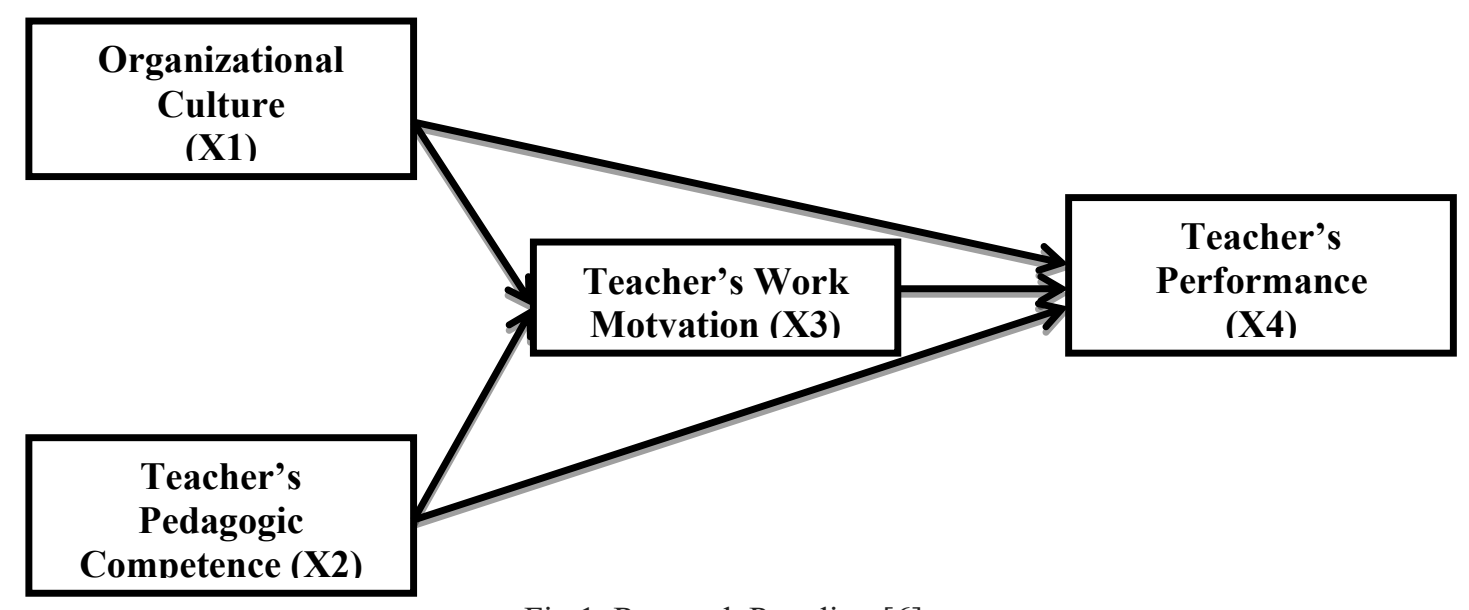

Fig 1. Research Paradigm[6]

This research was carried out at SMP Negeri Padang Bolak in North Padang Lawas consisting of 9 schools. The research method used is a survey research method to analyze the influence of one variable with another variable used path analysis. Path analysis requires a requirement for a significant form of linear regression relationship between variables. The population in this study were all state junior high schools at SMP Negeri Padang Bolak in North Padang Lawas consisting of 9 schools. Determination of the number of samples can be done by calculating statistics using the Slovin formula. The Slovin formula is used to determine the sample size of the population. Padang Bolak Sub-district has 9 Public Middle Schools. The nine 
State Junior High Schools in Padang Bolak Subdistrict have 170 educators.

Hypothesis testing

The research hypothesis proposed in this study is as follows:

1. Statistical hypothesis 1

Ho: $\rho 31 \leq 0$

Ha: $\rho 31>0$

2. Statistical Hypothesis 2

Ho: $\rho 32 \leq 0$

Ha: $\rho 32>0$

3. Statistical hypothesis 3

Ho: $\rho 41 \leq 0$

Ha: $\rho 41>0$

4. Statistical hypothesis 4

Ho: $\rho 42 \leq 0$

Ha: $\rho 42>0$

5. Statistical hypothesis 5

Ho: $\rho 43 \leq 0$

Ha: $\rho 43>0$

Information:

Ho: null hypothesis (which always states there is no influence)

Ha: Alternative hypothesis (which always states that there is influence)

p31: path coefficient between organizational culture and work motivation

232 : the path coefficient between pedagogic competence and work motivation

4 4: path coefficient between organizational culture and performance

4 4: path coefficient between job satisfaction and teacher performance

443 : path coefficient between work motivation and teacher performance

\section{DISCUSSION}

The Influence of Organizational Culture on the Work Motivation of Teachers at SMP Negeri Padang Bolak in North Padang Lawas District

The result of the second hypothesis testing is that there is a positive direct influence on organizational culture on the motivation of the work of teachers at SMP Negeri Padang Bolak in North Padang Lawas District. It is shown that the tcount of 3.789 is greater than $t$ table of 1.66 and the path coefficient is 0.294 and the significance of 0.000 is less than 0.05 . Based on this value, Ho is rejected and accepts Ha. So that it can be concluded that the hypothesis which states that organizational culture has a direct positive effect on the work motivation of teachers at SMP Negeri Padang Bolak in north Padang Lawas district is accepted.
The results of this study in accordance with the organizational culture carried out by the headmaster of the teachers will help the teacher in solving their problems in teaching. In addition, with the existence of organizational culture carried out by the principal, the teacher can find out his weaknesses and weaknesses in teaching. In organizational culture there is reinforcement and feedback. Strengthening and feedback from the principal as a supervisor will provide positive motivation as a result of coaching.

The Effect of Teacher's Pedagogic Competence on Teacher's Work Motivation at SMP Negeri Padang Bolak in north Padang Lawas District

The results of testing the third hypothesis, namely there is a positive direct influence of pedagogic competence on the motivation of the work of teachers at SMP Negeri Padang Bolak in north Padang Lawas district. It was shown that the tcount of 5.538 was greater than $t$ table of 1.66 and the path coefficient was 0.430 and the significance of 0.000 was less than 0.05 . Based on this value, Ho is rejected and accepts Ha. So it can be concluded that the hypothesis which states that pedagogic competence has a direct positive effect on the work motivation of teachers at Padang Bolak in north Padang Lawas district, is accepted.

Just as teacher pedagogic competence is the ability to manage student learning which includes understanding of students, designing and implementing learning, evaluating learning, and developing students to actualize their various potentials. Teacher's pedagogic competence is a factor that greatly influences the success of a group in carrying out the learning process. The work motivation of the teacher can provide high fighting spirit. In addition, teachers are also able to manifest themselves in relation to environmental demands and the development of science and technology. Teachers also have adequate quality of well-being so motivation arises to be independent, creative, and future-minded with their ability to track Science and Technology.

The Influence of Organizational Culture on the Performance of Teachers at SMP Negeri Padang Bolak in north Padang Lawas district

The results of the calculation of the fourth hypothesis, namely there is a positive direct influence of organizational culture on the performance of teachers at SMP Negeri Padang Bolak State in north Padang Lawas district. It is shown that the tcount of 3.930 is greater than $t$ table of 1.66 and the path coefficient is 0.330 and the significance of 0.000 is less than 0.05 . Based on this value, Ho is rejected and accepts Ha. So it can be concluded that the hypothesis which states that organizational culture has a direct negative effect on the teacher performance at SMP Negeri Padang Bolak in north Padang Lawas district is accepted. Because the results have a negative effect, it can be concluded 
that the larger the organizational culture, the lower the performance.

As an organizational culture that contains social elements, social norms, ways, habits, behavior and science as well as the overall social, religious, etc. structures, all intellectual and artistic statements that characterize a society as a differentiating barrier one school with another school. In improving teacher performance, an organizational culture is needed at school. The purpose of organizational culture in a school is to help and provide convenience for teachers to learn how to improve their ability to realize the learning goals of students. Organizational culture in improving teacher performance as previously mentioned is a factor that directly or indirectly influences teacher performance.

\section{The Influence of Teacher's Pedagogic Competence on the Performance of Teachers at Padang Bolak in north Padang Lawas Utara district}

The results of the calculation of the fifth hypothesis, namely there is a positive direct influence of pedagogic competence on the performance of teachers at SMP Negeri Padang Bolak in north Padang Lawas District. It was shown that the count of 2.210 was greater than $t$ table of 1.66 and the path coefficient was 0.197 and the significance of 0.029 was smaller than 0.05 . Based on this value, Ho is rejected and accepts Ha. So that it can be concluded that the hypothesis which states that pedagogic competence has a direct positive effect on the performance of teachers at Padang Bolak in north Padang Lawas district is accepted.

Teachers who have Pedagogic competencies will benefit their performance well. This can be seen from its ability to conduct learning activities effectively and efficiently so that the competence of students can improve. The performance of teachers who have Pedagogic Competencies can understand students, design and implement learning, evaluate learning and identify learners to actualize the various potentials they have. These abilities can affect the progress of their performance on an ongoing basis.

\section{The Effect of Teacher's Work Motivation on the Performance of Teachers at SMP Negeri Padang Bolak in North Padang Lawas district}

The results of the calculation of the sixth hypothesis, namely there is a positive direct influence of work motivation on the teacher performance at SMP Negeri Padang Bolak in north Padang Lawas Utara district. It was shown that the count of 2.094 was greater than t table of 1.66 and the path coefficient was 0.198 and the significance was 0.38 less than 0.05 . Based on this value, Ho is rejected and accepts Ha. So it can be concluded that the hypothesis which states that work motivation has a direct positive effect on the teacher performance at SMP Negeri Padang Bolak in north Padang Lawas district is accepted.

Teachers who have high work motivation can be seen from their diligence in facing assignments, their tenacity in facing difficulties, their interest in the problems being overcome, their independence in work, and being able to solve problems. Teacher's work motivation can affect its performance. The drive to do a high job will increase his ability to work.

\section{CONCLUSIONS}

The results of this study provide a number of information which can be summarized as follows:

1. Organizational culture has a direct effect on the level of work motivation. This finding concludes that the research hypothesis which states that organizational culture directly influences the work motivation of teachers at SMP Negeri Padang Bolak in North Padang Lawas district can be accepted.

2. Pedagogic competence directly influences the level of work motivation. This finding concludes that the research hypothesis which states that pedagogic competence directly influences the work motivation of teachers at SMP Negeri Padang Bolak in North Padang Lawas district can be accepted.

3. Organizational culture has a direct effect on the high and low performance of teachers. This finding concludes that the research hypothesis which states that organizational culture directly influences the performance of teachers at SMP Negeri Padang Bolak in North Padang Lawas District can be accepted.

4. Pedagogic competence has a direct effect on the high and low performance of teachers. This finding concludes that the research hypothesis which states that pedagogical competence has a direct effect on teacher performance at SMP Negeri Padang Bolak in North Padang Lawas district can be accepted.

5. Work motivation directly affects the high and low performance. This finding concludes that the research hypothesis which states that work motivation directly influences the performance of teachers at SMP Negeri Padang Bolak in North Padang Lawas District can be accepted.

\section{REFERENCES}

[1] Mulyasa, E. 2007. Menjadi Guru Profesional Menciptakan Pembelajaran Kreatif dan Menyenangkan. Bandung: Rosdakarya

[2] Suprihatiningrum, Jamil. 2013. Strategi Pembelajaran: Teori dan Aplikasi. Jogjakarta: AR Ruzz Media 
[3] Harijanto,Sutji. 2010. "Pengaruh Budaya Organisasi, Gaya Kepemimpinan, dan Kepuasan Kerja terhadap Kinerja Kepala Sekolah Menengah Atas di Jakarta Timur". Jurnal Manajemen Pendidikan. Jakarta. ISSN.112-339

[4] ibid

[5] Hamalik, Oemar. 2011. Kurikulum dan Pembelajaran. Jakarta: Bumi Aksara

[6] Sugiyono. 2007. Motode Penelitian Kuantitatif Kualitatif dan R\&D. Bandung: Alfabeta 